\title{
Gene Therapy for Bone Formation: In Vitro and In Vivo Osteogenic Activity of an Adenovirus Expressing BMP7
}

\author{
Renny T. Franceschi, ${ }^{1,4 *}$ Dian Wang, ${ }^{1}$ Paul H. Krebsbach, ${ }^{3}$ and R. Bruce Rutherford ${ }^{2}$ \\ ${ }^{1}$ Departments of Periodontics/Prevention/Geriatrics, School of Dentistry, University of Michigan, \\ Ann Arbor, MI 48109-1078 \\ ${ }^{2}$ Cariology/Endodontics/Restorative Sciences, School of Dentistry, University of Michigan, Ann Arbor, \\ MI 48109-1078 \\ ${ }^{3}$ Oral Medicine/Pathology/Oncology, School of Dentistry, University of Michigan, Ann Arbor, MI \\ 48109-1078 \\ ${ }^{4}$ Biological Chemistry, School of Medicine, University of Michigan, Ann Arbor, MI 48109-0606
}

\begin{abstract}
Bone morphogenetic proteins (BMPs) are well-established agents for inducing orthotopic and ectopic bone formation. However, their clinical usefulness as regenerative agents may be limited by a short in vivo half-life and low specific activity. BMP gene therapy is an alternative route for exploiting the bone-inductive activity of this class of molecules. To test the feasibility of this approach, we examined the osteogenic activity of AdCMV-BMP7, an adenovirus containing BMP7 cDNA under control of the CMV promoter that was constructed using Cre/lox recombination (Hardy et al. [1997] J. Virol. 71:1842-1849). Adenovirus vectors were shown to readily infect a wide variety of cell types in vitro including osteoblasts, fibroblasts, and myoblasts. COS7 cells transduced with AdCMV-BMP7 produced high levels of BMP-7 (approximately $0.5 \mu \mathrm{g} / 10^{6}$ cells). Furthermore, transduction of C2C12 murine myoblast cells with AdCMVBMP-7 suppressed the muscle phenotype and induced in vitro osteoblast differentiation. To test its in vivo biological activity, AdCMV-BMP7 was mixed with a bovine bone-derived collagen carrier $\left(10^{8}\right.$ plaque-forming units virus/site) and was implanted into mouse muscle and dermal pouches. In both cases, an ossicle containing cortical and trabecular bone and a clearly defined marrow cavity formed at the site of virus implantation within 4 weeks. These data demonstrate that AdCMV-BMP7 transduced cells produce biologically active BMP-7 both in vitro and in vivo and show that gene therapy by direct viral transduction using a virus/matrix implant may be a viable route for stimulating bone regeneration. J. Cell. Biochem. 78:476-486, 2000. ๑ 2000 Wiley-Liss, Inc.
\end{abstract}

Key words: adenovirus; BMP; osteogenesis

Use of recombinant bone morphogenetic proteins (BMPs) for bone regeneration represents one of the most promising emerging therapies for bone regeneration and is a viable alternative to autologous and homologous bone grafts. These molecules have the unique ability to al-

Grant sponsor: National Institute of Dental and Craniofacial Research; Grant numbers: DE11732, DE12211, DE12466, and DE12502; Grant sponsor: Michigan Multipurpose Arthritis Center; Grant number: AR20557; Grant sponsor: General Clinical Research Center; Grant number: M01-RR00042.

*Correspondence to: Dr. Renny T. Franceschi, Department of Periodontics/Prevention/Geriatrics, School of Dentistry, University of Michigan, 1011 North University Avenue, Ann Arbor, MI 48109-1078. E-mail: renny@@umich.edu Received 14 December 1999; Accepted 14 February 2000 Print compilation $\odot 2000$ Wiley-Liss, Inc. ter the differentiation pathway of mesenchymal cells toward chondrogenic and osteogenic lineages with the ultimate induction of endochondral bone at ectopic or orthotopic sites. Recombinant BMP2 and 7 have been shown to induce healing of segmental defects in a number of species including nonhuman primates [Yasko et al., 1992; Gerhart et al., 1993; Cook et al., 1994a, 1994b, 1995]. The successful use of BMPs to heal bony defects in humans has also been described [Bulstra, 1998; Geesink, 1999]. Although BMP protein therapy is well on the way toward being a clinically useful procedure, it is already apparent that BMPcontaining devices fail in a certain percentage of cases [Bulstra, 1998]. Reasons for failure may be related to a lack of optimal matrixes for 
controlled, sustained BMP delivery at the site of implantation, short biological half-life, and inability of recombinant molecule presentation after implantation to mimick the route of administration in vivo by a BMP-producing cell. Thus, although recombinant BMPs are promising therapeutic agents, there is still clearly a need for additional approaches to their use in bone regeneration.

Gene therapy was originally conceived as a means of correcting hereditary disorders [Friedmann, 1996]. However, more recent work is applying the same gene transfer technologies to situations where there is no underlying genetic defect, but, instead, a need to produce sustained amounts of a biologically active molecule. Some representative examples of this type of gene therapy include the introduction of cytotoxic or cystostatic genes into arterial smooth-muscle cells as a potential treatment for restenosis [Feldman et al., 1996], gene transfer of tumor suppressor genes to treat hepatocellular carcinoma [Anderson et al., 1998], and induction of genes into brain tissue to alter neurotransmittter/receptor levels as a potential treatment for epilepsy [O'Connor et al., 1997].

Such studies suggest that a further refinement of BMP therapy might be the use of gene transfer technology to convert connective tissue/stem cells at a designated localized site for bone regeneration into minireactors to produce sustained levels of BMPs. Unlike protein therapy, in which effects of the recombinant BMP are limited by protein degradation and inactivation at the site of application, gene transfer would be predicted to elicit sustained BMP production and more complete repair of the bony lesion. Adenovirus vectors have several characteristics making them well suited to this type of gene therapy, including the following.

1. Extremely high transduction efficiencies that are several orders of magnitude more efficient than traditional naked DNA or liposome-mediated gene transfer methods.

2. Ability to accommodate large (up to $7.5 \mathrm{~kb}$ ) cDNAs.

3. Growth to high titers.

4. Broad host-cell range allowing efficient infection of a wide variety of cell types.

5. Low pathogenicity in humans. And
6. Inability to integrate into the host genome, which avoids potential problems associated with insertional mutagenesis [Horwitz, 1990; Jaffe et al., 1992; Kirshenbaum et al., 1993; Le Gal La Salle et al., 1993; Ragot et al., 1993; Zabner et al., 1993; Chen et al., 1994].

The latter point is particularly important for regenerative therapies because the viral genome is not replicated with host cells and, hence, will eventually be lost by dilution and cell attrition. Although this may generally preclude use of adenovirus vectors for correcting monogenic hereditary disorders, it may actually be beneficial for bone regeneration, where only a finite period of transgene expression is desirable. Finally, adenovirus vector development is a rapidly evolving and improving technology. For example, new methods for vector construction using Cre/lox-mediated recombination have greatly shortened the time required for viral vector creation relative to the current widely used method of homologous recombination [Hardy et al., 1997].

There are two conceivable routes for the localized introduction of recombinant viruses to the desired site for bone regeneration: (1) virus is either directly implanted at the regeneration site where it infects neighboring cells, which begin producing recombinant protein (direct gene therapy); or (2) bone cell precursors are harvested, expanded, and infected with virus in vitro, followed by implantation to the regenerative site (indirect gene therapy). In either case, virus must be localized to the site targeted for bone formation either by adsorption to a suitable carrier or by containment and expression by transplanted cells. This is most readily accomplished using a space-filling matrix. Three recent reports described the induction of bone in ectopic and orthotopic sites using immortalized cell lines or marrow cells infected in vitro with adenoviruses expressing BMP2 or 4 that were subsequently injected into animals [Lieberman et al., 1998; Riew et al., 1998; Lou et al., 1999]. In addition, direct injection of an adenovirus expressing BMP2 into muscle was reported to induce ectopic bone [Musgrave et al., 1999]. However, no previous work has shown induction of bone by direct viral transduction from a carrier matrix in vivo. Although the approach of implanting ex 
vivo transduced cells holds promise, a direct in vivo gene transfer strategy obviates the need to obtain host cells from marrow or other sites and the ensuing morbidity from these procedures.

The present study was undertaken to test the feasibility of using direct gene therapy with a BMP7-expressing adenovirus adsorbed to a carrier matrix as a means of inducing bone formation. AdCMV-BMP7, a recombinant adenovirus containing BMP7 cDNA under the control of a viral promoter, was constructed using Cre/lox recombination [Hardy et al., 1997]. This virus induced the expression of functional BMP7 when transduced into cultured cells and stimulated osteoblastic differentiation of $\mathrm{C} 2 \mathrm{C} 12$ myoblasts in vitro. AdCMV-BMP7 was mixed with a bovine bone-derived collagen matrix and was shown to induce ectopic bone formation after implantation into subcutaneous and intramuscular sites in mice.

\section{METHODS}

\section{Adenovirus Construction}

AdCMV-BMP7 was constructed by Cre/lox recombination [Hardy et al., 1997] using reagents and protocols provided by Dr. Steven Hardy (Cell Genesys, Inc., Foster City, CA). Briefly, the method involves cloning full-length BMP7 (aka OP-1) cDNA (a gift from Dr. Herman Oppermann, Creative Biomolecules, Hopkinton, MA) into the BamH1 and Kpn1 sites of shuttle plasmid, pAdlox. This plasmid was cotransfected with psi5 adenovirus into CRE8 cells. Primary lysates were collected after 5 days and were used to reinfect CRE8 cells. The plaque assay method was used to purify virus from this secondary lysate. Each lysate was screened for the presence of BMP7 insert using polymerase chain reaction. Positive plaques were amplified in 293 cells and were purified by $\mathrm{CsCl}$ gradient ultracentrifugation. Purified virus was stored in $10 \%$ glycerol/phosphatebuffered saline and titered using a plaque formation assay. Normal titers were approximately $10^{10}$ plaque-forming units (pfu)/ml. AdRSVntlacZ, a recombinant adenovirus containing the bacterial $\beta$-galactosidase gene to which a nuclear localization sequence has been added [Roessler et al., 1993], was obtained from the University of Michigan Vector Core.

\section{Cell Culture}

MC3T3-E1 cells [Sudo et al., 1983] were cultured in ascorbic acid-free $\alpha$-modified Eagle's medium containing $10 \%$ fetal bovine serum (FBS), and $1 \%$ pen-strep as previously described [Franceschi and Iyer, 1992]. C2C12 cells [Yaffe and Saxel, 1977], a gift from Dr. Daniel Goldman (University of Michigan, Ann Arbor, MI), were maintained in Dulbecco's Modified Eagle Medium (DMEM), 10\% fetal bovine serum, and $1 \%$ pen/strep. Human gingival and pulp fibroblasts, obtained as surgical waste from the University of Michigan Dental School Clinic, were also maintained in DMEM, $10 \%$ FBS. Procedures for collection of human cells were in compliance with the Internal Review Board for Research on Human Subjects of the University of Michigan.

For in vitro transduction of cell lines, adenovirus at the desired titer was added to cells in serum-free $\alpha$-MEM. After $4 \mathrm{~h}$, FBS was added to a final concentration of $2 \%$ and medium was kept on cells for an additional $24 \mathrm{~h}$. Cells were then refed with complete medium containing $10 \% \mathrm{FBS}, 50 \mu \mathrm{g} / \mathrm{ml}$ ascorbic acid, $10 \mathrm{mM}$ $\beta$-glycerol phosphate, and fed at 48-h intervals for the duration of the experiment.

\section{Western Blot Quantitation of BMP7}

Conditioned medium from virally transduced COS7 cells was prepared by incubation in serum-free MEM- $\alpha$ for $24 \mathrm{~h}$. Dialyzed lyophilized samples were dissolved in 1x sodium dodecyl sulfate polyacrylamide gel electrophoresis (SDS-PAGE) loading buffer (2\% SDS, 2 M urea, $10 \mathrm{mM}$ dithiothreitol, $10 \%$ glycerol, 10 $\mathrm{mM}$ Tris $\mathrm{HCl}, 0.002 \%$ bromophenol blue), fractionated by SDS-PAGE on 10\% gels and electrophoretically transferred to a nitrocellulose membrane (Schleicher \& Schuel, Keene, NH). Anti-BMP7 antibody, a gift from Dr. Marc Charette (Creative Biomolecules), was used at a dilution of 1:1,000. A second antibody (horseradish peroxidase-conjugated goat anti-rabbit IgG) was used at a dillution of 1:10,000. Blocking and reaction with antibodies was conducted as previously described [Winnard et al., 1995]. Immunoreactivity was determined using the ECL chemiluminescence reaction (Amersham).

\section{Assays}

Alkaline phosphatase activity was measured in cell layers as previously described using a 
$p$-nitrophenylphosphate substrate [Manolagas et al., 1981], and DNA was determined according to the method of Schneider [Schneider, 1957]. To quantify mineralization in C2C12 cultures, cell layers were extracted in 15\% trichloroacetic acid and assayed for total phosphate using the method of Heinonen and Lahti [Heinonen and Lahti, 1981]. $\beta$-Galactosidase was measured with a commercially available kit (Tropix, Inc., Bedford, MA) using reagents and protocols provided by the manufacturer.

\section{In Vivo Analysis of Osteogenic Activity}

All procedures were approved by the University Committee on Use and Care of Animals and were in compliance with State and Federal laws. Adenovirus was mixed with guanidineextracted demineralized bovine bone powder (prepared as described by Sampath et al. [Sampath et al., 1990]) and was implanted into either subcutaneous or intramuscular sites in CD-1 mice. Normally, two subcutaneous and two intramuscular implants were placed in each animal. To facilitate comparisons, one control (AdRSVntLacZ virus implant) and one experimental (AdCMV-BMP7 virus implant) was placed in each site in a given animal. All operations were performed with animals under anesthesia achieved by inhalation of methoxyflurane (Mallinkrodt Veterinary, Mundelein, IL). Midlongitudinal skin incisions $1 \mathrm{~cm}$ long were made on the dorsal surface of CD-1 mice, and subcutaneous pockets were formed by blunt dissection. A single transplant containing $5 \mathrm{mg}$ of carrier and $10^{7}-10^{8}$ pfu virus was placed into each pocket and the wound was closed with surgical staples. Alternatively, a 1-cm incision was made on the lateral aspect of both thighs. A $0.5-\mathrm{cm}$ slit was then made in each quadriceps to create a pocket into which the viral preparation was inserted. The transplants were recovered 4 weeks after transplantation and were fixed and partially decalcified for 2 days in Bouin's solution (Sigma, St. Louis, MO). The transplants were then transferred to $70 \%$ ethanol and were embedded in paraffin. Sections of $5 \mu \mathrm{m}$ were deparaffinized, hydrated, and stained with hematoxylin and eosin.

\section{Statistical Analysis}

Where indicated, experimental data are reported as means \pm SDs of triplicate samples.

\section{RESULTS}

Adenovirus Vectors Transduce a Range of Cell Types Relevant to Craniofacial Regeneration

To assess the degree to which adenovirus vectors can transduce cells of interest for craniofacial regeneration, four representative cells lines expressing osteoblastic (MC3T3-E1 preosteoblasts), fibroblastic (from gingival and pulp biopsies), and muscle (C2C12 myoblasts) phenotypes were treated with AdRSVntLacZ, an adenovirus expressing bacterial $\beta$-galactosidase containing a nuclear localization sequence. As shown in Figure 1 and Table I, all cells were readily transduced by this vector, although the multiplicity of infection (m.o.i.) (pfu/cell) necessary to achieve high transduction varied between cell lines. Thus, pulp fibroblasts were more readily transduced (m.o.i. for $90 \%-100 \%$ transduction $=125-250$ ) than the other cell types (m.o.i. for $90-100 \%$ transduction $=500-1000$ ). Virally transduced cells exhibited no obvious morphological changes. Virus-derived $\beta$-galactosidase activity could be detected in MC3T3-E1 cells throughout the 3 -week culture period examined. However, when normalized to cell DNA, $\beta$-galactosidase activity decreased by $90 \%$ (Fig. 2A). This decline was mainly caused by the proliferation of nontransduced cells in the culture that became an increasingly larger percent of the total cell population with time (result not shown). To test whether introduction of virus could alter the differentiated phenotype of osteoblasts, MC3T3-E1 cells were mock-infected or transduced with AdRSVntlacZ at an m.o.i. of 500 and were examined for ability to form a mineralized extracellular matrix as would be expected if cells retained their phenotype after viral transduction. As shown in Figure 2B, both mock-infected and virally transduced cells mineralized to the same extent, indicating that expression of viral genes does not interfere with the differentiation process.

\section{Measurement of the Release of Adenovirus from a Bovine Bone Matrix Carrier}

As a prerequisite to in vivo viral transduction experiments, we sought suitable carriers for delivering virus to tissues. As noted above, a carrier matrix is necessary to localize the virus to a specific site and to serve as a suitable substrate for cellular invasion. Our initial efforts focused on a carrier composed of 
Mock
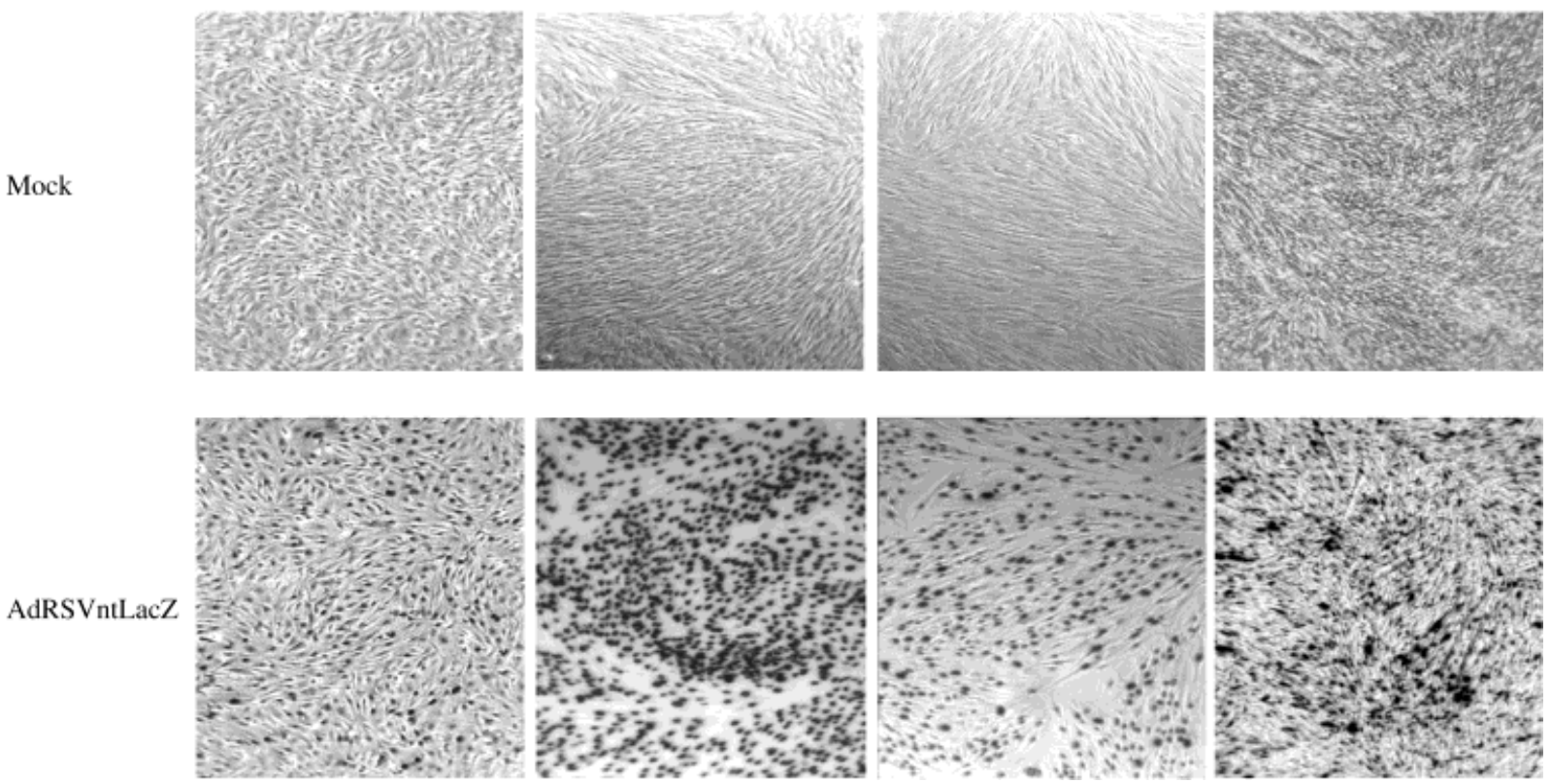

Fig. 1. In vitro transduction of cell lines with an adenovirus expressing bacterial $\beta$-galactosidase. Cell lines were transduced with the indicated titers of AdRSVntlacZ, a recombinant adenovirus containing the bacterial lacZ gene under control of an SV40 promoter. After $48 \mathrm{~h}$, cells were stained for nuclear $\beta$-galactosidase activity. Cell lines: MC3T3-E1 preosteoblasts; human gingival fibroblasts; human dental pulp fibroblasts, C2C12 myoblasts.

TABLE I. In Vitro Viral Transduction of Cell Lines ${ }^{\text {a }}$

\begin{tabular}{|c|c|c|c|c|}
\hline \multirow[b]{2}{*}{$\begin{array}{l}\text { Viral titer } \\
\text { (m.o.i.) }\end{array}$} & \multicolumn{4}{|c|}{ AdRSVnt-LacZ positive cell (\% total) } \\
\hline & MC3T3 & $\begin{array}{c}\text { Human gingival } \\
\text { fibroblast }\end{array}$ & $\begin{array}{l}\text { Human pulp } \\
\text { fibroblast }\end{array}$ & C2C12 myoblast \\
\hline 0 & 0 & 0 & 0 & 0 \\
\hline 125 & $35 \pm 2$ & $44 \pm 4$ & $92 \pm 5$ & $38 \pm 3$ \\
\hline 250 & $63 \pm 5$ & $82 \pm 7$ & $99 \pm 2$ & $79 \pm 2$ \\
\hline 500 & $84 \pm 8$ & $98 \pm 2$ & $100 \pm 0$ & $92 \pm 4$ \\
\hline 1,000 & $96 \pm 2$ & $100 \pm 0$ & $100 \pm 0$ & $98 \pm 2$ \\
\hline
\end{tabular}

${ }^{a}$ Cells were transduced with the indicated titer of AdRSVnt-LacZ and stained for $\beta$-galactosidase activity after $48 \mathrm{~h}$. Total and $\beta$-galactosidase-positive cells were then counted. m.o.i., multiplicity of infection.

guanidine-extracted demineralized bovine bone powder used for delivery of recombinant BMPs [Sampath et al., 1990]. AdRSVntlacZ in a $10 \%$ glycerol stock solution was mixed with the lyophilized matrix and added to cultures of MC3T3-E1 preosteoblast cells. After $48 \mathrm{~h}$, the number of cells with nuclear $\beta$-galactosidase staining was scored and compared with cells exposed to the same viral titer added directly to the culture medium. The carrier did not affect adenovirus transfection efficiency, indicating that the virus was able to freely diffuse from the matrix (result not shown).

\section{Construction and Testing of an Adenovirus Expressing BMP-7}

AdCMV-BMP7, an adenovirus expressing mouse BMP7 under control of a cytomegalovirus promoter, was constructed using Cre/lox recombination as described in the Methods section. The resulting virus was plaque purified and titered before use. Two criteria were used to assess whether this virus could direct the synthesis of functional BMP7 protein: (1) virus was used to transduce COS7 cells in culture, and the conditioned medium from these cells 

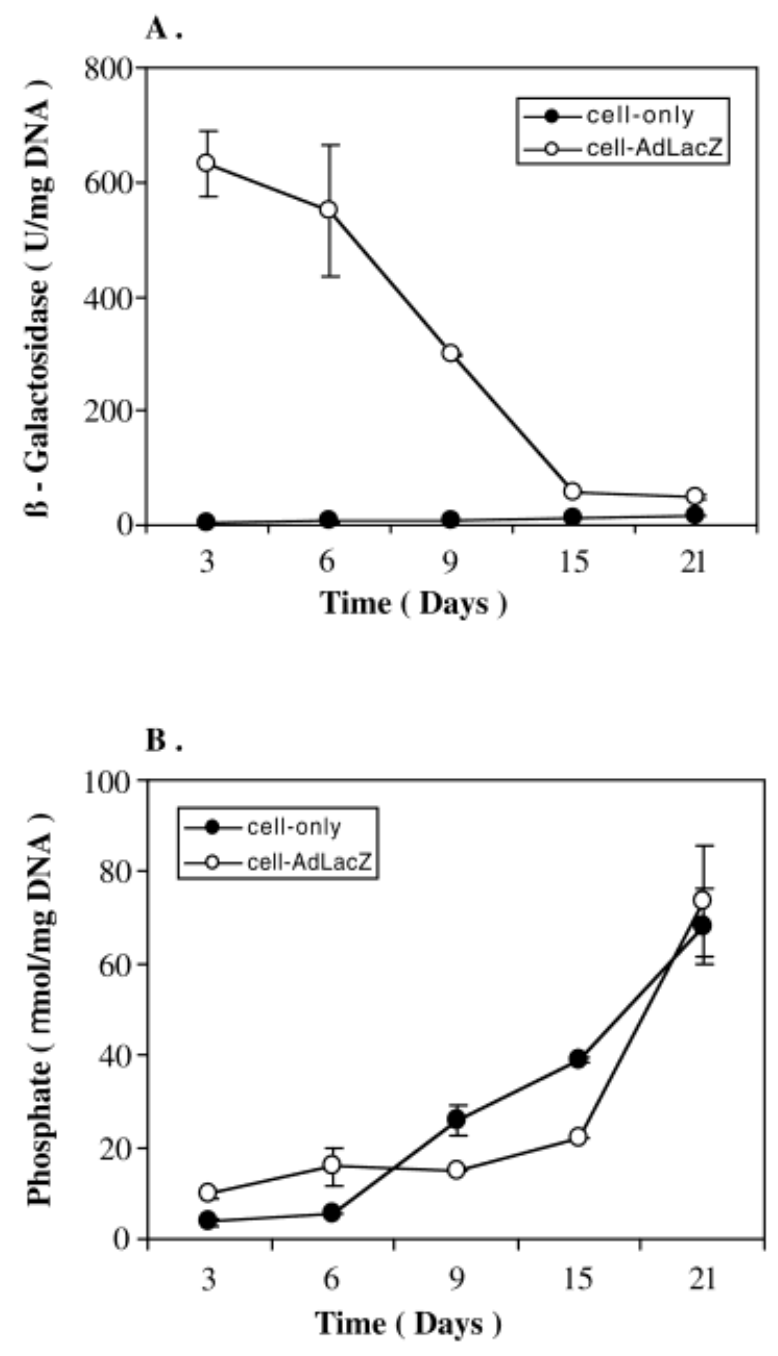

Fig. 2. Adenovirus infection does not alter the in vitro differentiation of preosteoblast cells. MC3T3-E1 cells were plated and transduced with 1,000 pfu/cell AdRSVntlacZ (open circles) or exposed to the transduction conditions in the absence of virus (closed circles) as described in the Methods section. Cells were then transferred to differentiation medium and examined at the times indicated for $\beta$-galactosidase activity (A) or matrixassociated mineral phosphate (B).

was analyzed for the presence of immunoreactive BMP7; (2) the ability of virus to induce the transdifferentiation of myoblasts to osteoblasts in vitro was examined in the $\mathrm{C} 2 \mathrm{C} 12$ myoblast cell line. Figure 3 shows a Western blot of conditioned medium from COS-7 cells transduced with either control virus (AdRSVntlacZ) or AdCMV-BMP7 that was probed with an antiBMP7 antibody. AdCMV-BMP7-transduced cells clearly produced immunoreactive protein that exhibited the same electrophoretic mobility as purified recombinant BMP7 on reduced and nonreduced gels. Using these Western blot data and correcting for sample concentration after lyophilization and resuspention, we estimate that COS-7 cells transduced with AdCMV-BMP7 at an m.o.i. of 50 produced approximately $0.5 \mu \mathrm{g}$ BMP $7 / 10^{6}$ cells.

The results shown in Figure 4 document the responsiveness of $\mathrm{C} 2 \mathrm{C} 12$ myoblasts to AdCMVBMP7 transduction. Other investigators previously showed that recombinant BMP2 stimulates the transdifferentiation of these cells from myoblasts to osteoblasts [Katagiri et al., 1994]. Because BMP7 and BMP2 share common receptors (i.e., BMPR1A/B [Baker and Harland, 1997]), we considered it likely that osteoblastic differentiation could be induced in these cells if AdCMV-BMP7 transduction resulted in the production of functional BMP7 protein. Cells were transduced with either control virus (AdRSVntlacZ) or AdCMV-BMP7 and cultured under conditions conducive to osteoblast differentiation and mineralization (i.e., in medium containing ascorbic acid and $\beta$-glycerol phosphate). AdCMV-BMP7 at an m.o.i. of 500 maximally stimulated the osteoblast marker, alkaline phosphatase, after 8 days in culture (Fig. 4A). Time course studies revealed that the response to virus in terms of either induction of alkaline phosphatase (Fig. 4B) or mineralization (Fig. 4C) required at least 6 days and continued to increase through day 10. AdCMV-BMP7 also dramatically altered cell morphology (Fig. 4D). Control cultures retained a myotube phenotype, whereas cells in the AdCMV-BMP7-treated cultures assumed a more rounded appearance and formed clearly defined mineralized nodules. These results are very similar to those reported for C2C12 cells treated with BMP2 protein and clearly indicate that viral transduction elicits the synthesis of biologically active BMP.

\section{In Vivo Osteogenic Activity of AdCMV-BMP7}

To test whether direct gene transfer of AdCMV-BMP7 into soft tissues of mice can induce ectopic bone formation, adenovirus $(2.5 \times$ $10^{7} \mathrm{pfu} / \mathrm{implant}$ ) was mixed with guanidineextracted demineralized bovine bone powder and implanted into subcutaneous or intramuscular sites of CD-1 mice. Control implants contained the same titer of AdRSVntlacZ. Virus implants were removed for histological analysis after 4 weeks. AdCMV-BMP7 formed bone at subcutaneous (six positives/seven implants) 


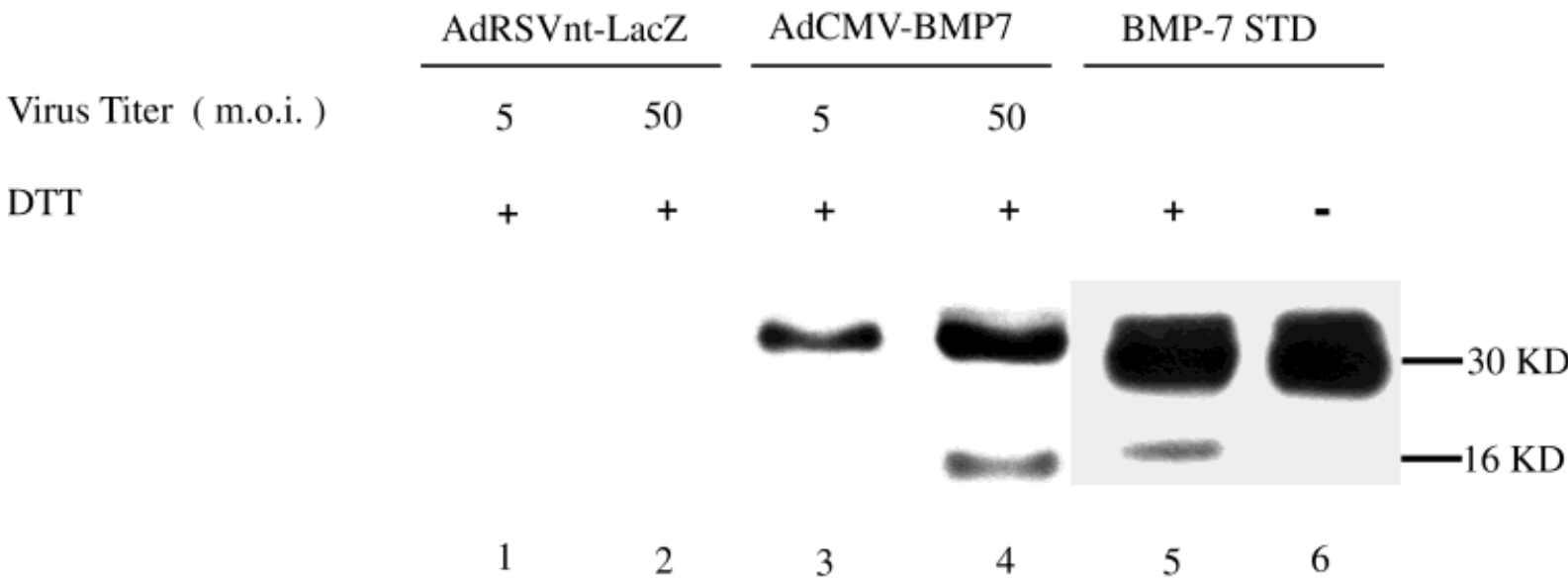

Fig. 3. In vitro production of BMP7 by COS-7 cells transduced with AdCMV-BMP7. An adenovirus expressing BMP7 under control of the CMV promoter was constructed by Cre/lox recombination as described in the Methods section. COS-7 cells were transduced with the indicated titer of AdRSVntlacZ (In 1, 2) or AdCMV-BMP7 (lanes 3, 4). After 24 h, cells were trans-

and intramuscular sites (seven positives/seven implants). In no case did control implants elicit an osteogenic response at either implant site. Representative histological sections are shown in Figure 5. Ossicles had a well-defined perimeter of cortical bone with trabeculae and an obvious marrow cavity containing hematopoietic cells as well as fatty marrow surrounding residual carrier (Fig. 5A,C). An examination under higher magnification revealed that mineralized areas contained osteocytelike cells within a bonelike ECM (Fig. 5E,F). In contrast, control implants (Fig. 5B,D) showed residual carrier matrix and infiltration with inflammatory cells, but no evidence of bone formation.

\section{DISCUSSION}

The use of gene therapy to stimulate bone regeneration represents a novel use of gene transfer technology, the goal of which is to alter levels of naturally occurring regenerative molecules to elicit a therapeutic response. Unlike traditional gene therapies designed to correct underlying genetic disorders, this approach seeks to enhance a natural reparative response by supplementing the regenerative site with additional therapeutic molecules. In this report, we describe the in vitro and in vivo biological activity of an adenovirus expressing BMP7. Cells transduced with AdCMV-BMP7 in vitro produced immunoreactive BMP that was electrophoretically indistinguishable from

ferred to serum-free medium and incubated for an additional $24 \mathrm{~h}$. Medium was dialyzed, concentrated by lyophilization, and aliquots were analyzed by Western blotting with antiBMP7 polyclonal antibody. Lanes 5 and 6 contain $300 \mathrm{ng}$ of purified, recombinant BMP7. Samples in Ins. 1-5 were reduced with $2 \mathrm{mM}$ dithiothreitol (DTT) before electrophoresis.

recombinant protein. Furthermore, this virus could induce the transdifferentiation of $\mathrm{C} 2 \mathrm{C} 12$ myoblasts into osteoblastlike cells in vitro. When mixed with a bovine bone-derived collagen carrier and implanted into CD-1 mice, AdCMV-BMP7 induced ectopic bone formation at both intramuscular and subcutaneous sites.

There are several hurdles that must be overcome for regenerative gene therapy to be successful:

1. Efficient methods must be developed for the localized introduction of foreign genes into target cells with a minimal host immune response.

2. Transferred genes must be expressed at adequate levels and for a sufficient time to effect a regenerative response, but must be inactivated once the therapeutic response has been achieved.

3. Viral vectors must be shown to safely infect the cells of interest with minimal side effects.

Adenovirus vectors are among the most efficient ways of delivering DNA to cells. We detected a clear osteoinductive response with viral titers as low as $10^{7} \mathrm{pfu} / \mathrm{implant}$ (approximately $60 \mathrm{pg}$ DNA). In contrast, although induction of bone in a nonunion fracture model has been reported using direct transfer of plasmid DNA encoding BMP4 and PTH [Fang et al., 1996; Bonadio et al., 1999], at present this mode of 

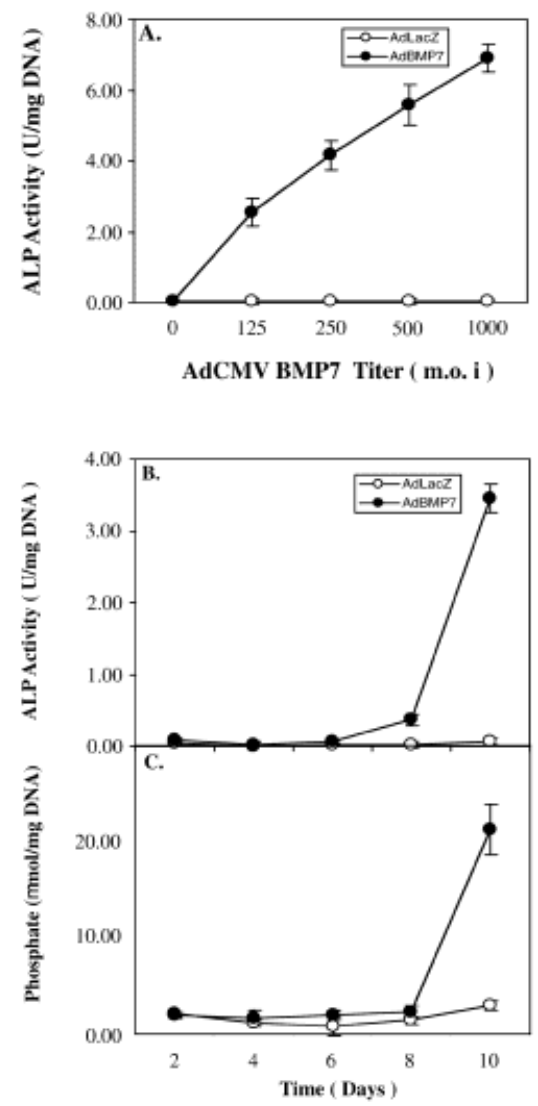

AdRSV-ntLacZ/

\section{3. B-Gal stained}

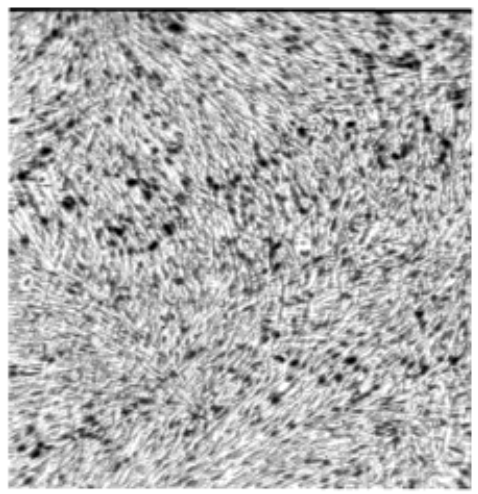

AdRSV-ntLacZ/

D 12. B-Gal unstained

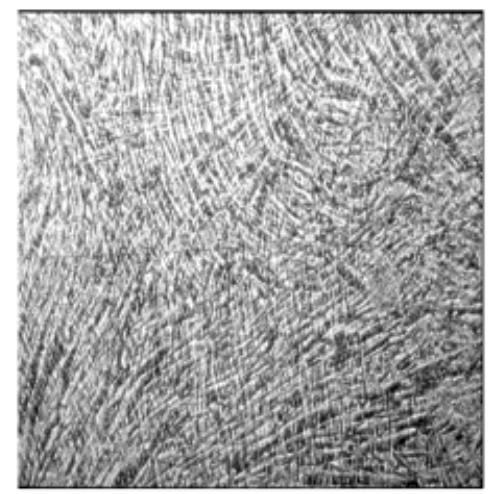

AdCMV-BMP7/ D 12. unstained

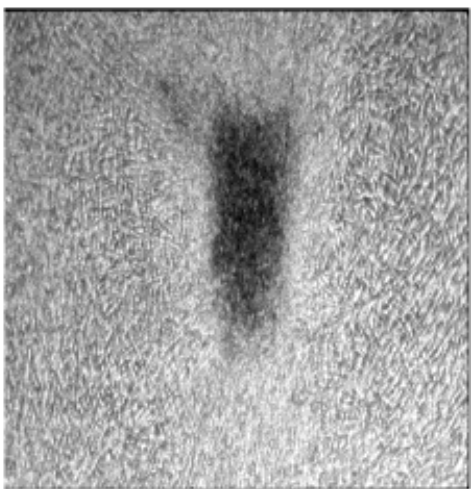

Fig. 4. In vitro induction of osteoblast differentiation by transduction of $\mathrm{C} 2 \mathrm{C} 12$ myoblasts with AdCMV-BMP7. A: Effect of viral titer on alkaline phosphatase induction. $\mathrm{C} 2 \mathrm{C} 12$ cells were transduced with the indicated titer of AdCMV-BMP7 (closed circles) or AdRSVnt lacZ (open circles) and grown in differentiating medium. Alkaline phosphatase activity was measured after 8 days. B, C: Time course of alkaline phosphatase induction and mineralization. $\mathrm{C} 2 \mathrm{C} 12$ cells were transduced with 500 pfu/cell AdRSVntlacZ (open circles) or AdCMV-BMP7 (closed circles). Cells were harvested at the times indicated for measurement of alkaline phosphatase (B) and total mineral phosphate (C). D: Cell morphology. C2C12 cells were treated as described in (B) and viewed under phase contrast after 12 days. One control sample (left panel, AdRSVntlacZ) was stained for $\beta$-galactosidase activity. Original magnification: $\times 100$. 

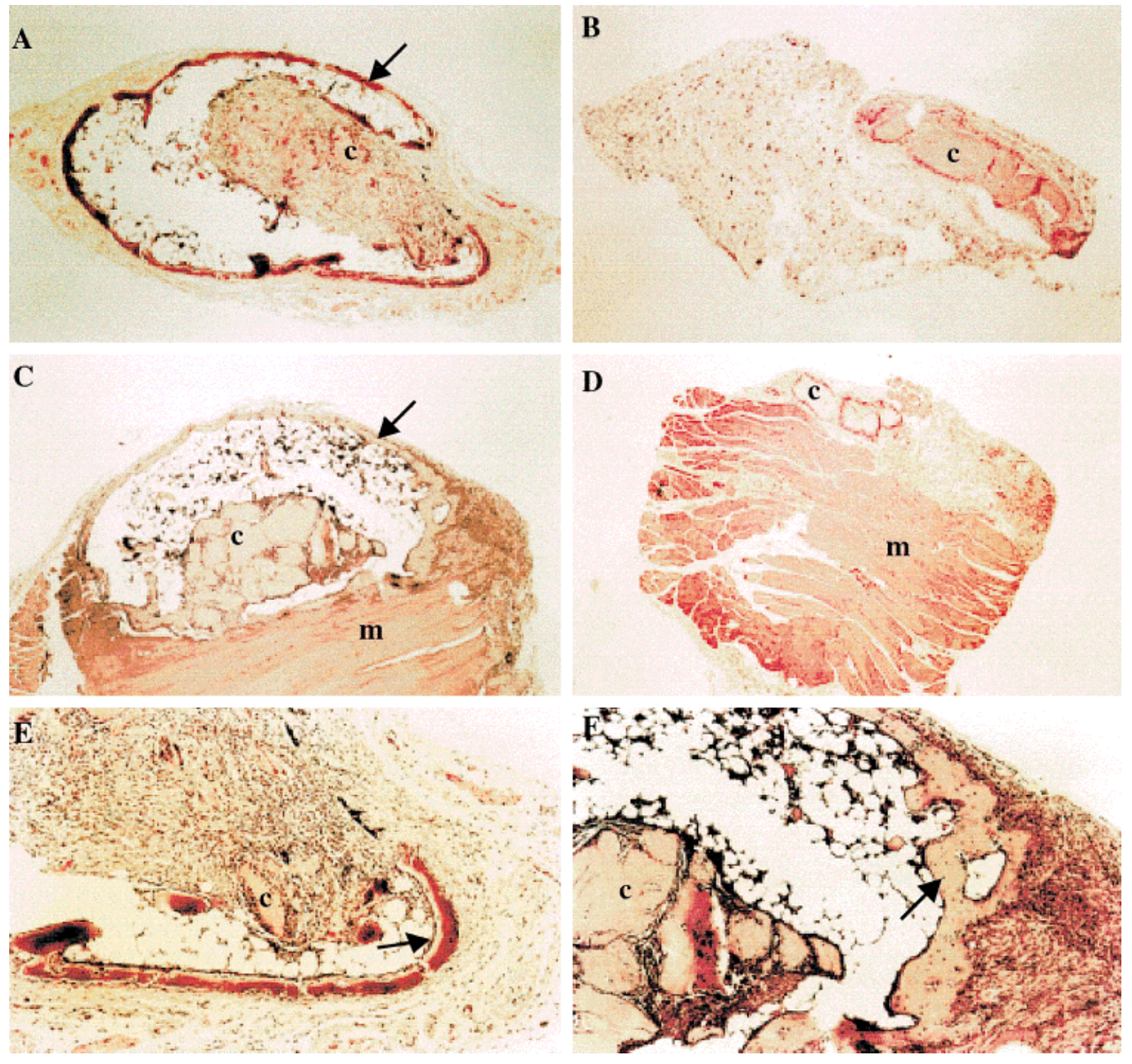

Fig. 5. In vivo bone formation. AdCMV-BMP7 $\left(2.5 \times 10^{7}\right.$ plaque-forming units) or control virus (AdRSVnt lacZ) in a guanidine-extracted, demineralized bovine bone matrix carrier was implanted into subcutaneous or intramuscular sites in CD-1 mice as described in the Methods section. After 4 weeks, implants were harvested for histological analysis. A: AdCMVBMP7, subcutaneous implant. This section shows a welldefined ossicle (arrow) with unresorbed carrier matrix in the center (c) surrounded by marrow. Original magnification: $\times 20$. E: Higher magnification $(\times 125)$ of the lower right corner of the section in (A) showing cortical bone with clearly delineated osteocytes (arrow) as well as hematopoietic and fatty marrow.

gene transfer is extremely inefficient. Amounts of plasmid DNA used to induce bone in these studies were in the range of 50-100 mg, approximately $10^{9}$ times more DNA than was used in our virus transduction experiments.

C: AdCMV-BMP7, intramuscular implant. The ossicle shown in this section (arrow) had a morphology similar to that formed at the subcutaneous site. Muscle adjacent to the virus implant is also apparent $(m)$. Original magnification: $\times 20$. F: Higher magnification $(\times 125)$ of the right side of the section in $(C)$ showing cortical bone with clearly delineated osteocytes (arrow) as well as hematopoietic and fatty marrow. B, D: Subcutaneous and intramuscular implants with control virus showing collagen carrier, but no bone formation. Possible inflammation and cell proliferation is apparent around the collagen carrier. Original magnification: $\times 20$.

Adenoviruses and, to a lesser extent, naked DNA, are known to elicit a host immune response [Wu et al., 1990; Orkin and Motulsky, 1995]. Immune rejection of gene therapy agents may severely limit the clinical utility of 
the current generation of vectors. In the case of the replication-deficient adenoviruses used in the present study, expressed viral coat proteins are the major immunogens that are known to cause acute immune responses in vivo. However, it is likely that second-generation adenoviral vectors in which most of the viral genome has been deleted (so-called gutted vectors) may be able to at least in part overcome this problem [Amalfitano et al., 1996].

In this first report, we have not examined the persistence of active AdCMV-BMP7 in transduced cells in vivo. Thus, we do not yet know whether the amount of BMP7 secreted or bone formed by virus would increase with time rather than plateau or regress, yet such information is clearly critical for assessing the utility of this approach for bone regeneration. Furthermore, bone formation was only examined at ectopic sites in vivo, yet therapeutic regeneration would normally be associated with existing bone where the mechanism and kinetics of bone formation would likely be very different. Detailed time course and dosing studies at both ectopic and orthotopic sites will be required to assess the persistence of the response to AdCMV-BMP7 transduction. Although it is unlikely that the replication-defective adenovirus used in this study could recombine with a wild-type viral genome and propagate, there is good evidence that viral gene expression can be detected in transduced cells for several weeks to months [Kass-Eisler et al., 1993]. Thus, persistent viral expression of BMP7 could be taking place in our system. If so, it may be necessary to use an adenovirus containing a regulated promoter to control transgene expression.

\section{ACKNOWLEDGMENTS}

This work was supported by National Institute of Dental and Craniofacial Research Grants DE11732, DE12211 (to R.T.F.), DE12466 (to R.B.R.) and DE12502 (to P.H.K.). Additional support was obtained from the Michigan Multipurpose Arthritis Center grant AR20557 and the General Clinical Research Center grant M01-RR00042. The authors also thank Ms. Janet Szczesay for excellent technical assistance.

\section{REFERENCES}

Amalfitano A, Begy CR, Chamberlain JS. 1996. Improved adenovirus packaging cell lines to support the growth of replication-defective gene-delivery vectors. Proc Natl Acad Sci USA 93:3352-3356.

Anderson SC, Johnson DE, Harris MP, Engler H, Hancock W, Huang WM, Wills KN, Gregory RJ, Sutjipto S, Wen SF, Lofgren S, Shepard HM, Maneval DC. 1998. p53 gene therapy in a rat model of hepatocellular carcinoma: intra-arterial delivery of a recombinant adenovirus [In Process Citation]. Clin Cancer Res 4:1649-1659.

Baker JC, Harland RM. 1997. From receptor to nucleus: the Smad pathway. Curr Opin Genet Dev 7:467-473.

Bonadio J, Smiley E, Patil P, Goldstein S. 1999. Localized, direct plasmid gene delivery in vivo: prolonged therapy results in reproducible tissue regeneration [In Process Citation]. Nat Med 5:753-759.

Bulstra S. 1998. Experiences in human delayed non-unions using OP-1 (BMP-7). Proceedings, First European Conference on Bone Morphogenetic Proteins. Abstract 62.

Chen SJ, Wilson JM, Muller DW. 1994. Adenovirusmediated gene transfer of soluble vascular cell adhesion molecule to porcine interposition vein grafts. Circulation 89:1922-1928.

Cook SD, Baffes GC, Wolfe MW, Sampath TK, Rueger DC. 1994a. Recombinant human bone morphogenetic protein-7 induces healing in a canine long-bone segmental defect model. Clin Orthop 301:302-312.

Cook SD, Baffes GC, Wolfe MW, Sampath TK, Rueger DC, Whitecloud TS, 3rd. 1994b. The effect of recombinant human osteogenic protein-1 on healing of large segmental bone defects. J Bone Joint Surg Am 76:827-838.

Cook SD, Wolfe MW, Salkeld SL, Rueger DC. 1995. Effect of recombinant human osteogenic protein-1 on healing of segmental defects in non-human primates. J Bone Joint Surg Am 77:734-750.

Fang J, Zhu YY, Smiley E, Bonadio J, Rouleau JP, Goldstein SA, McCauley LK, Davidson BL, Roessler BJ. 1996. Stimulation of new bone formation by direct transfer of osteogenic plasmid genes. Proc Natl Acad Sci USA 93: 5753-5758.

Feldman LJ, Tahlil O, Steg PG. 1996. Adenovirusmediated arterial gene therapy for restenosis: problems and perspectives. Semin Interv Cardiol 1:203-208.

Franceschi RT, Iyer BS. 1992. Relationship between collagen synthesis and expression of the osteoblast phenotype in MC3T3-E1 cells. J Bone Miner Res 7:235-246.

Friedmann T. 1996. Human gene therapy-an immature genie, but certainly out of the bottle. Nat Med 2:144147.

Geesink RGT, Hoefnagels NHM, Bulstra SK. 1999. Osteogenic activity of OP-1 bone morphogenetic protein (BMP-7) in a human fibular defect. J. Bone Joint Surg [Br] 81-B:710-718.

Gerhart TN, Kirker-Head CA, Kriz MJ, Holtrop ME, Hennig GE, Hipp J, Schelling SH, Wang E. 1993. Healing segmental femoral defects in sheep using recombinant human bone morphogenetic protein. Clin Orthop 293: 317-326.

Hardy S, Kitamura M, Harris-Stansil T, Dai Y, Phipps ML. 1997. Construction of adenovirus vectors through Crelox recombination. J Virol 71:1842-1849.

Heinonen JK, Lahti RJ. 1981. A new and convenient colorimetric determination of inorganic orthophosphate and its application to the assay of inorganic pyrophosphatase. Anal Biochem 113:313-317. 
Horwitz MS. 1990. Adenoviridae and their replication. In: Fields B, Knipe DN, editors. Virology. New York: Raven Press. p 1679-1740.

Jaffe HA, Danel C, Longenecker G, Metzger M, Setoguchi Y, Rosenfeld MA, Gant TW, Thorgeirsson SS, StratfordPerricaudet LD, Perricaudet M, Pavirani A, Lecocq J-P, Crystal RG. 1992. Adenovirus-mediated in vivo gene transfer and expression in normal rat liver. Nat Genet 1:372-378.

Kass-Eisler A, Falck-Pedersen E, Alvira M, Rivera J, Buttrick PM, Wittenberg BA, Cipriani L, Leinwand LA. 1993. Quantitative determination of adenovirusmediated gene delivery to rat cardiac myocytes in vitro and in vivo. Proc Natl Acad Sci USA 90:11498-11502.

Katagiri T, Yamaguchi A, Komaki M, Abe E, Takahashi N, Ikeda T, Rosen V, Wozney JM, Fujisawa-Sehara A, Suda T. 1994. Bone morphogenetic protein-2 converts the differentiation pathway of $\mathrm{C} 2 \mathrm{C} 12$ myoblasts into the osteoblast lineage [published erratum appears in J Cell Biol 1995;128:following 713]. J Cell Biol 127:1755-1766.

Kirshenbaum LA, MacLellan WR, Mazur W, French BA, Schneider MD. 1993. Highly efficient gene transfer into adult ventricular myocytes by recombinant adenovirus. $\mathrm{J}$ Clin Invest 92:381-387.

Le Gal La Salle G, Robert JJ, Berrard S, Ridoux V, Stratford-Perricaudet LD, Perricaudet M, Mallet J. 1993. An adenovirus vector for gene transfer into neurons and glia in the brain. Science 259:988-990.

Lieberman JR, Le LQ, Wu L, Finerman GA, Berk A, Witte ON, Stevenson S. 1998. Regional gene therapy with a BMP-2-producing murine stromal cell line induces heterotopic and orthotopic bone formation in rodents. J Orthop Res 16:330-339.

Lou J, Xu F, Merkel K, Manske P. 1999. Gene therapy: adenovirus-mediated human bone morphogenetic protein-2 gene transfer induces mesenchymal progenitor cell proliferation and differentiation in vitro and bone formation in vivo. $J$ Orthop Res 17:43-50.

Manolagas SC, Burton DW, Deftos LJ. 1981. 1,25Dihydroxyvitamin D stimulates the alkaline phosphatase activity of osteoblast-like cells. J Biol Chem 256: 7115-7117.

Musgrave DS, Bosch P, Ghivizzani S, Robbins PD, Evans $\mathrm{CH}$, Huard J. 1999. Adenovirus-mediated direct gene therapy with bone morphogenetic protein-2 produces bone [In Process Citation]. Bone 24:541-547.

O'Connor WM, Davidson BL, Kaplitt MG, Abbey MV, During MJ, Leone P, Langer D, O'Connor MJ, Freese A. 1997. Adenovirus vector-mediated gene transfer into human epileptogenic brain slices: prospects for gene therapy in epilepsy. Exp Neurol 148:167-178.
Orkin SH, Motulsky AG. 1995. Report and recommendations of the panel to assess the NIH investment in research on gene therapy. http://www.nih.gov/news/ panelrep.html.

Ragot T, Vincent N, Chafey P, Vigne E, Gilgenkrantz H, Couton D, Cartaud J, Briand P, Kaplan JC, Perricaudet M, et al. 1993. Efficient adenovirus-mediated transfer of a human minidystrophin gene to skeletal muscle of $\mathrm{mdx}$ mice. Nature 361:647-650.

Riew KD, Wright NM, Cheng S, Avioli LV, Lou J. 1998. Induction of bone formation using a recombinant adenoviral vector carrying the human BMP-2 gene in a rabbit spinal fusion model. Calcif Tissue Int 63:357-360.

Roessler BJ, Allen ED, Wilson JM, Hartman JW, Davidson BL. 1993. Adenoviral-mediated gene transfer to rabbit synovium in vivo. J Clin Invest 92:1085-1092.

Sampath TK, Coughlin JE, Whetstone RM, Banach D, Corbett C, Ridge RJ, Ozkaynak E, Oppermann H, Rueger DC. 1990. Bovine osteogenic protein is composed of dimers of OP-1 and BMP-2A, two members of the transforming growth factor-beta superfamily. J Biol Chem 265:13198-13205.

Schneider WC. 1957. Determination of nucleic acids in tissues by pentose analysis. Methods Enzymol 3:680684.

Sudo H, Kodama H-A, Amagai Y, Yamamoto S, Kasai S. 1983. In vitro differentiation and calcification of a new clonal osteogenic cell line derived from newborn mouse calvaia. J Cell Biol 96:191-198.

Winnard RG, Gerstenfeld LC, Toma CD, Franceschi RT. 1995. Fibronectin gene expression, synthesis, and accumulation during in vitro differentiation of chicken osteoblasts. J Bone Miner Res 10:1969-1977.

Wu DP, Gilkeson GS, Armitage J, Reich CF, Pisetsky DS. 1990. Selective recognition of DNA antigenic determinants by murine monoclonal anti-DNA antibodies. Clin Exp Immunol 82:33-37.

Yaffe D, Saxel O. 1977. Serial passaging and differentiation of myogenic cells isolated from dystrophic mouse muscle. Nature 270:725-727.

Yasko AW, Lane JM, Fellinger EJ, Rosen V, Wozney JM, Wang EA. 1992. The healing of segmental bone defects, induced by recombinant human bone morphogenetic protein (rhBMP-2). A radiographic, histological, and biomechanical study in rats [published erratum appears in J Bone Joint Surg Am 1992;74:1111]. J Bone Joint Surg Am 74:659-670.

Zabner J, Couture LA, Gregory RJ, Graham SM, Smith AE, Welsh MJ. 1993. Adenovirus-mediated gene transfer transiently corrects the chloride transport defect in nasal epithelia of patients with cystic fibrosis. Cell 75:207216. 